ISSN: 2162-3104 Print/ ISSN: 2166-3750 Online

Volume 6, Issue 1 (2016), pp. 283-307

(C) Journal of International Students

http://jistudents.org/

\title{
A Critical Review of \\ International Students’ Adjustment Research from a Deleuzian Perspective
}

\author{
Gene Vasilopoulos \\ University of Ottawa (Canada)
}

\begin{abstract}
The author in this paper critically reviews recent literature on international student language and adjustment to Western Anglophone universities. Two streams of research are discussed: the problem-solving approach guided largely by positivist epistemologies and quantitative methodologies contrasted to the post-structuralist language and identity framework employing qualitative methods. Limitations to both perspectives include the reliance on fixed constructs of language and adjustment, the isolation of interrelated variables, the attempt to establish linear correlational/causative relationships, the essentialization of identity, and the inability to explain change and variance. Deleuzian ontology of 'becoming' and assemblage is put forward as a framework to better understand the complexity, unpredictability, and ever-changing process that international students face when co-adapting to the their new academic community
\end{abstract}

Keywords: International students, language learning, adjustment, literature review, Deleuze,

For several decades, academics have been interested in international student experience, devoting considerable attention to the issue of language and adjustment to Western Anglophone universities. Today, with an increasing push to internationalize higher education and increase enrollment (Trilokekar \& Kizilbashm, 2013), the issue of international student experience is perhaps more pressing than ever. Times have changed, and so has international education and international student experience where 
"now, it is more difficult to remain local than to become international" (Phillips \& Schweisfurth, 2014, p.xi). Globalization provides near infinite opportunities for students to travel overseas, obtain international degrees from transnational institutions, join cosmopolitan cyber communities, and seek employment abroad. International education and international student experience has evolved to reflect global trends of neo-liberalism, mobility, migration, and communication. This calls into question the utility of existing theoretical and methodological frameworks to address the dynamic reality of international students as multilingual transnationals shuttling between super diverse and rapidly changing communicative contexts (Gargano, 2012).

The lag in theory and methods is not specific to international student research but has been made loud and clear in the greater field of socioculturally oriented linguistics and cultural studies (DeCosta, 2010; Canagarajah, 2013, 2006; deFina \& Perrino, 2014). Closely related, the global trends of increased migration, communication, and knowledge exchange culminate in the internationalization of higher education and international student experience; thus, what is needed is not more of the same. The scholarship requires alternative theoretical and methodological frameworks that reflect the complexity, interconnection, and heterogeneity of experience and possibility. This paper examines how language, language learning, and international student adjustment has been conceptualized in the past, and more importantly, proposes new directions for the future.

At the outset, the methods, theoretical framework, and rationale guiding this analysis are presented. A brief review of key approaches in international student language and adjustment research identifies twostreams: the problem solving approach guided largely by positivist/postpositivist epistemologies and quantitative methodology contrasted by poststructural/constructivist approaches employing qualitative methods. While the scholarship on international students adjustment recognizes the complexity of the transition process, current approaches continue to conceptualize, measure, observe, and represent essentialized, linear, and reductionist relationships. There is a need to explore alternative epistemological frameworks that can capture the dynamics of language in an age of transnationalism. In response, Deleuze and Guattari's (herein referred to as D \& G) concept of "becoming” and "assemblage" (1987) are proposed as a conceptual framework to examine the complex series of co-adaptive changes and transformations experienced by individual international students within the broader context of the university.

Theoretically, this paper is inspired by D \& G ontology which guides the following analysis. Deleuzian ontology is a fundamental departure from traditional principles that have long guided Western philosophical and scientific thought (Jackson \& Mazzei, 2012). From a Deleuzian perspective, 
data is "multiplicitous-it is not dependent on being stabilized or known in an onto-epistemic project of qualitative research 'interpretation' and 'analysis'” (Jackson \& Mazzei, 2012, p.114). Analysis from a D \& G perspective entails rearranging, reorganizing, and refitting together the theory (my readings of Deleuze) to the data (my readings of the literature on international student language and adjustment) and developing a new understanding of how pieces are connected.

This analysis critically reviews the existing research on language and international student adjustment research to assess the capability of current approaches to reflect the trends in the globalization of language (Canagarajah, 2006; deFina \& Perrino, 2014), international education (Knight, 2011), and international student experience. With increased transnational populations and the changing face of Western higher education, this review is both necessary and timely. As a result, the focus of this paper is on themes and shortcomings that emerged from a critical review of the selected literature.

\section{LITERATURE REVIEW}

\section{The Problem-Solving Approach: Focus on Individual Factors}

Contemporary conceptualizations of international student adjustment distinguish between the psychological and the sociocultural (Searle \& Ward, 1990; Ward \& Kennedy, 1992). Psychological adaptation concerns affective responses including a sense of well-being and self-esteem, as well as physical well-being (Ward, Bochner, \& Furnham, 2008). Sociocultural adaptation is based on behavioral responses related to how effectively an individual links to the new society, such as competence in managing tasks required for daily intercultural living (Ward et al., 2008). Successful adaptation, psychologically and socio-culturally, also relates to sociodemographic variables, such as education level, academic performance, prior cross-cultural experience, host language proficiency, family income, and perceived cultural distance (Coles \& Swami, 2012). Recently, research has focused on these individual factors with the aim of problem-solving, that is how to reduce stress and enhance the positive aspects of adjustment and experience in the host university/community (Ward et al., 2008).

General findings in the problem-solving stream have been relatively conclusive: (1) English language as a challenge to academic success and barrier to social interaction (Andrade \& Evan, 2009; Mallinckrodt \& Leong, 1992; Olivas \& Lee, 2006; Ward \& Kennedy, 1992). These studies suggest that international students encounter great problems communicating with others in English, especially in an academic setting; (2) 
Social and cultural challenges noting challenges with social integration, isolation, homesickness, financial crisis, and family stress (Mallinchrodt \& Leong, 1992; Sandhu \& Asrabadi, 1991); (3) Lack of social support and few recourses for emotional stress and help seeking behaviors (Poyrazli et al., 2004; Ward et al., 2008); and (4) Challenges in establishing relationships outside of their shared ethnic community (Olivas \& Lee, 2006; Ward et al., 2008) specifically relating to lack of compatible social support within the host community. However, international student adjustment is far more complex that the listing above.

\section{Complex Variables and Complex Relationships}

First, the literature is rich with seemingly interchangeable terms of 'adjustment', 'acculturation', and 'adaptation'; however, these terms represent significantly different understandings of international student experience. For example, Andrade's (2006) meta-analysis of the literature employs Ramsay, Baker, and Jones' (1999) construct of adjustment as "the fit between students and the academic environment and may examine issues such as learning styles, study habits, education background, culture and language proficiency” (p.134). On the other hand, De Araujo's (2011) literature review draws on Al-Sharideh \& Goe's (1998) definition of adjustment as "a transition process that unfolds over time as students learn to cope with the exigencies of the university environment" (p. 2). Notice that while Ramsay et al., focus on the final the product that is the "fit", AlShariedeh and Goe emphasize the ongoing process that adjustment entails. Other lines of research such as Zhou, Jindal-Snape, Topping, \& Todman's (2008) discussion of theoretical models of culture shock in international student higher education employs Berry's (1997; 2006) acculturative stress and adaptation framework where acculturation is viewed as the dual process of cultural (group) and psychological (individual) change that takes place as a result of contact between two or more cultural groups and their individual members (Berry, 2006). Clearly, studies categorized under and/or relating to international student adjustment research may not be examining the same phenomenon.

Secondly, although the findings in the problem-solving stream are classified in distinct categories, the themes overlap and interconnect in nonlinear patterns. Firstly, the extensive range of variables include: individual psychological traits, sociocultural factors, socio-demographic differences, language proficiency and attitudes, prior learning, social interaction, and social context. These variables represent constructs which can be conceptualized in various ways hence producing distinct results. For example, Yeh \& Inose (2003) relate interaction to social connectedness, a 
construct that goes beyond immediate daily direct face-to-face interaction. Alternatively, Perruci \& Hu's (1995) employ the construct of social satisfaction which includes the category of marital status, the factor that they found to be the greatest determinant of social satisfaction in the host context. Other researchers have focused on social interaction vis-à-vis international students and local students (Wright \& Schartner, 2013; Trice, 2004). Interestingly, Myles \& Cheng's (2003) study found contact with conationals and fellow international students as opposed to domestic students, to be desired and sufficient. Given the wide range of variables and the multiple conceptualizations of individual constructs, it is not surprisingly that the precise relationship between relevant factors has yet to be conclusively identified.

Reaching conclusive findings on cause/effect or correlational relationships has been equally challenging. For example, Poyrazli et al. (2006) found that language difficulties were not central to social adjustment. Instead, language was mediated through academic achievement; students with lower levels of academic achievement reported lower levels of English proficiency and more overall adjustment strain. Similarly, Wright \& Schartner (2013) problematize the widely accepted assumption that the greater length of time in the host community, coupled with increased language proficiency would lead to more interaction with host nationals. Their analysis produces a relationship more complex than positive correlations or cause/effect. The role of motivation, agency, and personality also suggests a circular rather than linear pattern: Yang, Noels, and Samure, (2006) found that while target language proficiency contributes to social interaction with host nationals, both variables also positively impact selfconfidence creating a cyclical effect where increased self-confidence leads to more interaction further improving language development. This virtuous circle also leads to increased academic success.

\section{Fixed Conceptualizations of Language}

Similar to the multiple conceptualizations of adjustment and social interaction, the greater body of research tends to oversimplify the construct of language by overlooking language development over time. Language proficiency (perceived and real) changes in terms of confidence and opportunities to interact with host nationals (Coles \& Swami, 2012; Gu, Schweisfurth, \& Day, 2009); however, quantitative analysis is often based on prior English proficiency test scores taken before entry into the host institution. There are few longitudinal studies (with the exception of Zhang \& Mi, 2013; Cheng \& Erben, 2012), yet long-term investigation is 
warranted as development may not follow expected linear progress (Wright \& Schartner, 2013).

The assumption that language proficiency directly and positively correlates to academic achievement is also simplified in the research. Linguistic difficulties manifest in listening and oral communication, lack of knowledge of local contextual references, inadequate vocabulary, and the struggles to meet the requirements for academic writing (Sawir, Marginson, Forbes-Mewett, Nyland, \& Ramia, 2012). Yet few studies examine the four language skills, reading, writing, listening, and speaking (with the exception of Sawir et al., 2012; Zhang \& Mi, 2013). Likewise, few studies differentiate between disciplines despite linguistically 'heavy' disciplines such as humanities and social sciences reportedly posing greater challenges than hard sciences (Sawir, 2011; Berman \& Cheng, 2001). Instead, most research relies on measures of linguistic proficiency through standardized tests developed to assess the four skills separately such as TOEFL, TOEIC, and IELTS, but these instruments have been criticized by both students and faculty as unreliable reflections of English competence (Trice, 2003; Uysal, 2010). Not surprisingly, other factors such as academic and content knowledge, personal characteristics, and teaching and learning support also need to be considered in understanding language proficiency, academic achievement, and adjustment (Carroll, 2005; Cheng, Myles, \& Curtis, 2004; Feast, 2002).

Viewing language as an outcome that can be measured objectively by a standardized test undermines factors fundamental to language learning such as communicative competence, self-regulation, and self-efficacy (Phakiti, Hirsch, \& Woodrow, 2013) and self-determination, or what Li and Gasser (2005) refer to cross-cultural self-efficacy. Yang and her colleagues (2006) point out, strong agency helps students to acquire language proficiency, and ease adjustment stress (Sawir et al., 2012). Agency is fundamental to developing language proficiency (Yang et al., 2006) initiating and sustaining contact with host nationals (Trice, 2004) and facilitating adjustment (Sawir et al., 2012). However, as Wright \& Schartner caution, agency and language proficiency cannot be isolated from the role of social context (2013).

\section{Overlooking Social Context}

Social context plays a critical role in understanding international students' language use and adjustment to their new environment. Acculturation studies of new immigrants show language proficiency and self-worth become linked in a virtuous circle with positive local interactions (and the minimization of discrimination), contributing to a sense of 
belonging and the confidence to act (Hullet \& Witte, 2001; Matsumoto et al., 2004). Socio-constructivist views of language (Kramsch, 1997) maintain that interlocutors (instructors and domestic students) and social context (university support, perceived discrimination, and social networks) play a central role in international student social interaction (e.g. Robertson et al., 2000; Schweisfurth \& Gu, 2009; Wright \& Schartner, 2013; Grayson, 1997; Perrucci \& $\mathrm{Hu}, 1995)$. Language difficulties isolate international students from local persons, including students promoting reliance on in-group networks with co-nationals (Hayes \& Lin, 1994; Ippolito, 2007; Li \& Kaye, 1998). Yet, the association between L2 proficiency and the L2 community is not that simple. As Gardner and Lambert (1972) have demonstrated, improved proficiency does not imply a desire for greater interaction with native-speakers, nor does proficiency correlate with increased interaction with host nationals (Myles \& Cheng, 2003).

Clearly, the role of social context on language and adjustment cannot be determined simply through the perspective of individual students. Yet, in the research, the role of host nationals, domestic students, teaching, academic and institutional support, community attitudes, and social networks, cumulatively, is still ill-defined, difficult to measure, or absent altogether. Furthermore, an overwhelming majority of the studies (with the exception of Robertson et al., 2000) collected data exclusively from international students or exclusively from faculty. Hence, while research emphasizes the importance of positive connections within the institution and the host community, there is little insight from these parties.

\section{The Language Socialization and Language Identity Approach}

Echoing my comments above, another line of research adopts a post-structuralist approach and focuses on language socialization (Duff, 2008) and language identity (Norton, 2005). These approaches draw on Lave \& Wenger's communities of practice (1991) to emphasize social context. Specific to international student adjustment research, Duff (2010) proposes that 'academic discourse' is a language and culture unique to Western academia. From the language socialization perspective, adjustment is viewed as a process of socialization where newcomers gradually move towards fuller participation in a given community by interacting with more experienced community members. Becoming a member of the community requires identity negotiation as the individual adopts the practices of the new group. Research shows that language, cultural identity, and social interaction with the host community are central to academic experience of non-native speakers (Morita, 2004; Hayashi, 2013; Halic, Greenberg, \& Paulus, 2009). This perspective emphasizes the important role that native- 
speakers and fellow non-native speaking peers play in repositioning subjectivities (Hung \& Hyun, 2010), developing the L2, participating in the community (Morita, 2004; Lee, 2009; Seloni, 2011; Hayashi, 2013; Robertson et al., 2000), and feeling a sense of belonging (Morita, 2004; Casanave \& Li, 2008).

The related field of study abroad research has also become increasingly interested in second language learning and identity. With its fertile conditions for inter-cultural communication, the study abroad scholarship confirms the importance of the quality and quantity of interaction with native speakers on linguistic and non-linguistic aspects of language acquisition (Jackson, 2008; Kinginger, 2013; Benson et al., 2013). Moreover, research confirms the process of language development and identity negotiation is continuous, ever-changing, and at times contradictory (Lin, 2009; Jackson, 2011).

Addressing the increasingly globalized nature of language and international student adjustment, further research explores transnational identity (Gargano, 2012) demonstrating the significance of social networks (both within the host, and with the home, community) in identity maintenance and/or formation while abroad (Gomes \& Alzougool, 2013). Given the prevalence of native language/culture connections while in the host community, consideration of these networks are necessary to understanding adjustment. The home/host context dichotomy is further deconstructed in terms of future immigration and travel plans to places other than the native home land or country of study. These academic and professional trajectories play an important role in shaping international students' daily experiences at their new universities (Gargano, 2012; Phelps, 2013; Yang \& Noels, 2012).

\section{Conceptualizations of International Students}

Though the language socialization and language and identity framework has moved international student research beyond the positivist/post-positivist paradigm, challenges inherent to post-structuralist theories and methodologies remain. First, there is ambiguity on how to conceptualize "international students". So far, the majority of research referred to in this paper generally define international students as "individuals enrolled in institutions of higher education that are on temporary student visas and are non-native English speakers" (Andrade, 2006). Grimshaw (2011) points out that homogenizing international student experience is tricky due to the diversity of international student programs ranging from short-term intensive language training courses to extended post-secondary degrees spanning several years. 
As a response, researchers have turned to linguistic identifiers such as Native Speaker-Non-Native Speaker (Berman \& Cheng, 2001), multilinguals (Mortita, 2004; Hayashi, 2013), and additional language learners (Hyun \& Hung, 2010) to circumvent the perils of relying on legal definitions, yet, this approach is also problematic. For instance, Yang et al.'s (2006) research may be more specific to language learning rather than international student adjustment because of the broad sampling criteria which included landed immigrants and permanent residents. While their sample represented non-Canadian students, it did not represent students that intentionally travelled to the host context for the purpose of education. Furthermore, international students are more than speakers of multiple languages; it is essential to consider their transnational experiences (Gargano, 2012; Grimshaw, 2011), transnational connections (Gomes \& Alzougool, 2013), and their transnational futures (Phelps, 2013).

\section{Essentialized Identities}

Undoubtedly, the identity framework has been useful in highlighting the complexity and circularity of language learning via identity negotiation; however, a critical limitation lies in the operational definition of the identity construct. From a post-structuralist perspective, identity is unfixed, dynamic, fluid, and ever-changing (Norton, 1995, 1997, 2000). Nevertheless, the research continues to employ pre-given fixed characteristics in defining individual identities. For example, individuals may be defined by race, gender, nationality, language, occupation, background, and family, among others. This is commonly seen in the section describing the participants' demographics (Gargano, 2012). This line of thinking perpetuates Western academic discourse where 'they' (international students) are often reduced to stereotypical characterizations and contrasted unfavorably with domestic students (Grimshaw, 2011; Magyar \& Robinson-Pant, 2011; Al-Youssef, 2013). Instead, scholars advocate for a more nuanced conceptualization of non-Anglophone/nonWestern students which acknowledges the complex and dynamic array of interconnected multiple identities an individual may possess (Holliday, 2005; Kubota \& Lin, 2006).

Methodologically, traditional qualitative research instills reductionism and over-generalization. For identity based research, it is apparent that identity cannot be packed into a clear-cut variable, yet identity is still categorized and measured in linear and thematic ways (MenardWarwick, 2005). Furthermore, data analysis typically employs coding for thematic similarities among participants, thus presenting only dominant experiences (MacLure, 2013). Most importantly, while identity studies may 
be essential to understanding instances of language learning (and notlearning), the nature of identity remains unclear and is unable to explain continuity and change (Menard-Warwick, 2005). As Wright \& Schartner (2013) point out, new frameworks required to understand language and international student experience need to decipher the threshold point at which change occurs and account for highly individualized variation.

\section{Homogeneous Processes}

Homogeneous presuppositions also plague the language socialization perspective which emphasizes conformity within the established community. Critics point out that academia and academic discourse are not static and fixed but in constant flux changing to meet new characteristics of the field (Street, 1996; Zamel, 1997). Furthermore, socialization is generalized as a uniform process the same for all novices. This relates to earlier concern over similarities among international students based on nationality, cultural and linguistic background (Grimshaw, 2011). Finally, the language socialization approach has been critiqued be being overly deterministic by viewing individuals as passively complying irrespective of potential resistance (Duff, 2010). Similar to the language and identity framework, shortcomings of the language socialization approach extend to its methodological capability to document the gradual and highly elusive process of change (Schecter \& Bayley, 2004).

\section{Summary}

So far, this discussion has reviewed the recent research on language and international student adjustment. Two streams of research were identified. First, the problem-solving approach largely characterized by quantitative studies attempts to decipher linear causative relationships between isolated variables such as language proficiency, interaction, motivation/agency, attitudes, academic success and socio-cultural adjustment. For many, these findings are considered as conclusive; however, several studies highlight the intricacy of variables and difficulty in determining causal and correlational relationships.

The next stream of research adopts a post-structuralist approach to language identity and language socialization. This approach employs qualitative methods and is considerably more fluid with inclusive conceptualizations of language, identity, and communities. Moreover, the recognition of multilingualism and transnationalism incorporates past histories, and the future possibility of global mobility, reflecting the reality of modern international education. However, within the post-structuralist research, theoretical and methodological limitations include the inability to 
conceptualize and investigate heterogenous and ever-changing subjectivities. Naturally, the inability to explain individual change relates to the thorny issue of how social context contributes to consistency or change, and the role of human agency in this equation.

\section{DELEUZE-GUATTARI ONTOLOGY}

\section{Deleuze-Guattari 'Becoming'}

'Becoming' and difference are central to Deleuze-Guattari ontology which responses to Western philosophy's reductionism and linearity in explaining social and cultural phenomenon. Traditional philosophy continues to apply universal characteristics to define social groups such as the category of woman marked by consistent traits juxtaposing the counter category of man, again marked by stable traits (Jackson, 2013). Rejecting pre-given static identities, 'becoming' emphasizes the potential for change as a fluid process of interactions and transformations that work to destabilize rigid structures that bind us to the status quo (Martin \& Kamberelis, 2013). These overarching well-defined macro structures and categories are referred to as molar (D \& G, 1987). In contrast to the normative, the molecular functioning on the micro level are singularities that break away from what is fixed and expected, thereby destabilizing the predictability of the system. Emphasizing change, difference, and what happens in between presumably fixed constructs (Martin \& Kamberelis, 2013), 'becoming' and assemblage are better equipped to examine interrelation, complexity, non-linearity, variation, and unpredictability in the process of transformation.

Applying D \& G's ontology to language and literacy education, Masny (2013) proposes 'becoming' as the process of reading the word, world, and self. This goes beyond the view of literacy as reading comprehension, to how events impact an individual's understanding of themselves and their surroundings. In terms of language and literacy, 'becomings' arise because of exposure and experiences that deterritorialize by causing ruptures and transformations which impact and move the individual. Stability is regained only to be reterritorialized again in an ongoing cycle. 'Becoming' is marked by consistent reshaping and redefinition of external and internal conditions which creates 'being' or individuation. Notably, 'becoming' contrasts the perilous practices described by Gimshaw (2011) and Maygar \& Robinson-Pant (2011) of 'otherisation' based on socio-demographic characteristics such as nationality, linguistic and cultural background. Furthermore, 'becoming' emphasizes the micro-level specificities that make individuals and their process of individuation unique. 


\section{Deleuzo-Guttarian Assemblage}

'Becoming' occurs in the assemblage. In A Thousand Plateaus, D \& G write that “all we know are assemblages” (1987, p. 25). Assemblage can best be understood as composition of heterogeneous elements or objects that enter into relation, interacting to make, unmake, and remake one another. An international student is an assemblage with a multitude of factors to consider: linguistic and academic background, personality, past and present experiences and circumstances. Collectively, international students and domestic students form a part of a classroom assemblage which is placed in the greater assemblage of the university. As concentric circles, assemblages overlap and interconnect smaller systems within larger systems. All the separate, yet intersecting, elements and objects work together forming a system of which the student is a part. The complexity of this mangle parallels the experiences of international students moving between cultures and contexts, repositioning and adjusting to their new space. However, it is important to note that within the assemblage there is no pre-established hierarchy; human actors and institutions are de-centered creating new questions of human subjectivity (D \& G, 1987).

\section{De-centered Actors}

Fundamental to Deleuze's assemblage is the notion of the decentered subject placing humans on an equal plane with other elements that make up the collective. This is in stark contrast to the long-embedded Cartesian humanist view of the individual as a rational actor and autonomous thinking subject (D \& G, 1987). Deleuze puts forward a subject who is part of the assemblage, but also the product of events within the assemblage the individual becomes an effect of events and experiences in life (Deleuze, 1990). Repositioning the individual in a flattened nonhierarchial mangle of social context takes away rational thought, the will to choose, and the ability to fully control their circumstance.

The interrelation between humans and their context is multidirectional: human actors simultaneously produce and are produced. As D \& G explain, "There is no such thing as either man or nature now, only a process that produces the one within the other and couples the machine together (1987, p. 2). Where does the individual begin and where does he/she end? In the system of the assemblage, forces, flows, and intensities connect and interact, and within this system, all parts and components are equal: there is no human hierarchy, no individual center, and no participant subjectivity. This applies to individual students, instructors, and administrators, and the university as an institution. This also applies to language and the language that students use. 
Human agency within the assemblage should be clarified. Being de-centered in the assemblage does not mean that humans are hapless victims to the social context they find themselves in. Instead, Deleuze and Guattari (1987) draw on post-humanist materialist which can be understood through Pickering's (1993) concept of collective agency. This differs from individual human agency where individuals are free-willed and selfdetermined. Likewise, it differs from the view of human agency expressed through collectives, or a collectivity (such as institutions) that exerts humanlike agency, with intentionality and directionality. From D \& G's posthuman materialist standpoint, human agency, either individual or collective is bound with and exercised through materiality including not only objects and tools but also the bodily and the affective. Hence, one entity, be it an individual or institution is not in superior possession of agency (Pickering, 1993). Instead, agency is distributed and emerges between the elements, temporally and unpredictably, changing, growing, and breaking, only to regrow (D \& G, 1987).

D \& G's post-humanist approach to individual agency circumvents what Block (2013) calls the agency-structure dilemma in second language acquisition (SLA) that is, reaching a shared understanding of how much or how little, social structure impacts individuals ability to act. For Block, the disparate views of agency represented within SLA research range from individuals as autonomous actors overcoming social barriers to access, develop, and use language to reflect their individuality, to research emphasizing social inequality, imposed positioning, and the constraints surrounding language learning and use (2013). Questions of agency have also received growing attention in the international student research as scholars attempt to account for the role of individual self-determination for successful adjustment (Sawir et al., 2012; Yang \& Noels, 2012).

\section{De-centered Language}

From a Deleuze-Guattari perspective, language plays a role in understanding 'becoming', but as mentioned above, language is not the only element to consider: "in assemblages, you find states of things, bodies, various combinations of bodies, hodge-podges; but you also find utterances, modes of expression, and whole regimes of signs' (D \& G, 1987, p. 177). The de-centering of language in the assemblage suggests that language alone is not key to understanding interaction, experience, or adjustment; other elements must be considered such as organizations, social structures, networks, relationships, norms, values, and the unique multiplicities that make up context. The Deleuze-Guattari post-human 
materialist view of language gives way to recognizing the power of forces other than words to compose human reality such as materiality and affect.

Affect has received considerable attention as evidenced in Pavlenko's comprehensive review of the affective turn in second language acquisition research (2013). Emotions in language research include motivation (Gardner \& Lambert, 1972), anxiety (Horwitz, Horwitz, \& Cope, 1986), investment (Norton, 1995, 1997, 2000), belonging (McElhinny, 2010) and the ideal-self (Dornyei \& Ushioda, 2009). More generally, Pavlenko observes research trends moving away from explaining what affect is, that is, identifying emotive variables induced in language learning, to what affect does and how emotions impact language learning (2013). Yet, D \& G's conceptualization of affect differs considerably from affective constructs employed in mainstream SLA. For D \& G affect cannot be essentialized, identified, labelled, and measured, a procedure widely accepted and practiced in positivist/post-positivist and post-structural language research.

From a Deleuzian perspective, actors, entities, materiality, and affect work together powered by collective agency which operate the assemblage. Just as affect is de-centered, in this mangle, language is also decentered leading to Mazzei's (2013) notion of voice as collective. She explains this through the notion of Voices without Organs:

(V)oice cannot be thought as existing separately from the milieu in which it exists, it cannot be thought as emanating 'from' an individual person. There is no separate, individual person, no participants in an interview study to which a single voice can be linked-all are entangled. (p. 734)

Linguistic decisions are not made autonomously by individual speakers but through forces, flows, and intensities between the entities within the assemblage. In the case of spoken utterances, voice is not a product of the speaker's independent agency. Likewise, when a student demonstrates language development through the application of new grammar, lexicon, or improved communicative ability, the perspective of collective voice would infer that these developments are not exclusively of the student's own accord. Displays of normative language use or creative language use are not the choices of the speaker but are the voice of the assemblage.

If we consider 'becoming' as constant change, and movement in unpredictable non-linear multiplicities, then language use, and the affective, should also be viewed as non-static, influx, and unpredictable. This perspective has radical implications for how language and identity have traditionally been conceptualized. Repositioning the individual in a non- 
hierarchical mangle of social context takes away rational thought and the will to choose when and how to respond to stimuli. Repositioning the individual departs from fixed essentialized traits (identity) that contain and presume predictable outcomes. Repositioning the individual also addresses the identity paradox of why some traits change while others remain constant and how (re)negotiation and (re)construction of multiple identities occurs. Viewing the subject as de-centered resonates with the pressing limitation of the role of human agency and insurmountable social structures and phenotypic traits that cannot be modified. Hence, it is no longer a question of agency but about 'happenings'. It is not about what the person does, but what the assemblage produces. This circumvents the endless structure/agency dilemma in SLA, which presumably relates, and will spread, to international student adjustment research.

\section{Reconceptualizing Adjustment}

Through collective agency, all the elements in the assemblage work toward an undetermined outcome. In the research presented above, we see many differing conceptualization of international student experience such as the degree of interaction with host nationals (Yang et al., 2006; Wright \& Schartner, 2013), levels of acculturative stress (Yeh \& Inose, 2003), reported academic and social satisfaction (Perrucci \& Hu, 1995), academic achievement (Berman \& Cheng, 2001), socialization to into the dominant group (Morita, 2004), active participation (Lee, 2009) positionality (Hyun \& Hung, 2011), human security (Sawir et al., 2012), and belonging (Guo \& Chase, 2011; Ryan \& Viete, 2009; Curtin, Strewart, \& Ostrove, 2012). However, all the constructs listed above move towards a pre-established end-point. This includes fitting into the community measured through interaction with locals, being socialized into the community by more experienced community members, reaching a fixed end state such as being at ease, feeling a sense of belonging, or feeling secure. Not surprisingly, all these constructs have the same starting point of international students as disadvantaged. To reiterate, these presumptions are dangerous as they erroneously stereotype and essentialize international student experience as one and the same (Gargano, 2012; Phelps, 2013; Grimshaw, 2011).

On top of a homogeneous essentialized international student, it is assumed that the university is a homogeneous system, and that adjustment would follow an equally unvarying process. Such uniformity is hardly the case, yet existing approaches are ill-equipped to take into account the variety of unexpected circumstances and challenges that international students will encounter. Time, space, and highly individualized characteristics also make the concept of adjustment, adaptation, 
acculturative stress, and belonging relative. From the perspective of 'becoming' in the assemblage, current theoretical approaches are illequipped to understand the dynamics of change.

Additionally, the concept of adjustment, socialization, or adaptation assumes that there is an active agent initiating the fit. Early research from the problem-solving approach examined students' characteristics and proposed means of coping, assimilating, and adapting to improve their adjustment process. Subsequent frameworks focused on improvements to teaching, counseling services, bridging programs, and remedial language courses. Again, there is an active agent (the student, the instructor, the program developers, and/or the administrators) working to control the context and improve conditions within the system to make a better fit. In the assemblage, it is impossible to determine the centered actor. For example, a student that was very strong academically in their home university may not be as strong in the host university. This student may feel disappointed and frustrated in being demoted from the previous high performance status; however, if newer students arrive and face greater academic challenges, they may fill the positions of "low achieving" moving other students up in the ranks. While the student him/herself has not changed, the surrounding circumstances have changed his/her positioning. It is impossible to attribute this event to a single agent.

Moving beyond individual human agency to institutional agency, we can see similar contradictions. It is erroneous to assume that the university actively and independently creates the conditions of the university environment. Consideration must be given to the countless elements and entities in the greater assemblage which shape institutional administrative policies and practices. For example, neo-liberal economic policies have had a profound impact on the internationalization of higher education (Trilokekar \& Kizilbash, 2013) as seen in Canada's federal action plan to double international student enrollment (Department of Foreign Affairs and International Trade, 2012). This objective would mean a dramatic shift in student demographics in Canadian universities. Constant flux within separate entities leads to consequences. Inadvertently, modifications in one element will affect others. The change in student population will certainly impact how universities approach international education. The multidirectional forces of push-pull lead to undetermined outcomes within the assemblage. Arguably, this is a more realistic reflection of the transitions that Canadian universities will soon be facing. 


\section{CONCLUSIONS}

As the wealth of research on language and international student adjustment to Western universities reflects, the past 20 years has seen significant expansion in the volume, scope, and complexity of international higher education (Altbach \& Knight, 2007; Knight, 2011). Attracting international students has become a top institutional priority and initiative that parallels broader global trends of increased mass mobility, migration, communication and exchange. This paper presents a critical review of the literature on language and IS adjustment and discusses the application of DeleuzeGuattari ontology to international student language and adjustment research. 'Becoming' is presented as a construct to uncover the micro-level difference and uniqueness experienced by international students as they engage in their new context. From the perspective of assemblage, the role of context is placed in the forefront de-centering individuals, institutions, and language. Moreover, 'becoming' in the assemblage is presented as an alternative to the notion of adjustment to emphasize that there is no one-size-fits-all conceptualization of what being an international student is, or in fact, should be. Adjustment and acculturation needs to be more sensitive to change and how events, speed, and intensities alter the starting conditions with which the student enters the assemblage, how the university makes each individual student different, and how the university becomes different with each new student.

DeFina and Perrino (2013) suggest that perhaps it is time to requestion the theories and methods that essentialize language practices and intercultural experience. Applying Deleuzian ontology to language and international student research unearths a wealth of possibilities for future inquiry. It opens the field to experimental theories and methodologies that reject fixed binaries, pre-established linear relationships, and the search for cause/effect. It opposes the view of universities as static with polarized views of home vs. host universities breaking down the barrier between 'us' and 'them' which implies that there is one academic practice for new students adopt. Western higher education is not a monolithic entity immune to change. Accordingly, it takes into account the greater complexity of international education in institutions of higher learning from macro-level federal immigration policies and international student recruitment initiatives to administrative level institutional strategies, programs and support, and further to teaching and learning practices in the classroom, and finally, to the microscopic role of affect in everyday social interaction. In an age marked with unprecedented global movement and connection, an ontological framework that emphasizes change, difference, interconnection, and unpredictability is warranted to examine the individuality of 
international student experience and celebrate the diversity they bring to Western Anglophone classrooms.

\section{REFERENCES}

Al-Youssef, J. (2013). An international approach to teaching and learning from a UK university management perspective: Implications for international students' experience on campus. In S. Sovic \& M. Blythman, (Eds.). International Students Negotiating Higher Learning: Critical Perspectives. (pp. 54-66) NY: Routledge.

Altbach, P. G., \& Knight, J. (2007). The internationalization of higher education: Motivations and realities. Journal of Studies in International Education, 11, 290-305.

Andrade, M. (2006). International students in English-speaking universities: Adjustment factors. Journal of Research in International Education, 5, 131-154.

Andrade, M. S. \& Evans, N. W. (Eds.) (2009). International Students: Strengthening a Critical Resource. Lanham, Rowman \& Littlefield Education.

Benson, P., Barkhuizen, G., Bodycott, P. \& Brown, J. (2013). Second Language Identity in Narratives of Study Abroad. London: Palgrave MacMillan.

Berman, R. \& Cheng, L. (2001). English academic language skills: Perceived difficulties by undergraduate and graduate students and their academic achievement. Canadian Journal of Applied Linguistics, 4, 2540.

Berry, J. W. (1997). Immigration, acculturation, and adaptation. Applied Psychology, 41, 5-34.

Berry, J. W. (2006). Mutual attitudes among immigrants and ethnocultural groups in Canada. International Journal of Intercultural Relations, 30, 719-734.

Block, D. (2013). The structure and agency dilemma in identity and intercultural communication research. Language and Intercultural Communication, 13, 126-147.

Canagarajah, S. (2006). Negotiating the local in English as a lingua franca. Annual Review of Applied Linguistics, 26, (197-219).

Canagarajah, S. (2013). Agency and power in intercultural communication: Negotiating English in translocal spaces. Language and Intercultural Communication, 13, 202-224.

Carroll, J. (2008). "Lightening the load". Teaching in English, learning in English. In Carrol, J., \& Ryan, J (Eds.). Teaching international students: Improving learning for all (pp. 35-42). London: Routledge. 
Casanave, C. \& Li, X. (Eds.). (2008). Learning the Literacy Practices of Graduate School: Insiders' Reflections on Academic Enculturation. Mahwah, NJ: Erlbaum.

Coles, R. \& Swami, V. (2012). The socio-cultural adjustment trajectory of international university students and the role of university structures: A qualitative investigation. Journal of Research in International Education, $11,87-100$.

Cook, V. (1999). Going beyond the native-speaker in language teaching. TESOL Quarterly, 33, 185-209.

Curtin, N., Stewart, A.J., \& Ostrove, J.M. (2012). Fostering academic selfconcept: Advisor support and sense of belonging among international and domestic students. American Educational Research Journal. DOI: 10.3102/0002831212446662

deAraujo, A.A. (2011). Adjustment issues of international students enrolled in American colleges and universities: A literature review. Higher Education Studies, 1, 2-8.

DeCosta, P. (2010). Let’s collaborate: Using developments in global English research to advance socioculturally oriented SLA identity work. Issues in Applied Linguistics, 18, 99-124.

deFina, A. \& Perrino, S. (2013). Transnational identities. Applied Linguistics, 34, 509-515.

Deleuze, G. (1990). The Logic of Sense. New York: Colombia University Press.

Deleuze, G. \& Guattari, F. (1987). A Thousand Plateaus: Capitalism and Schizophrenia. Minneapolis: University of Minnesota Press.

Department of Foreign Affairs and International Trade, Canada. (2012) International Education: A Key Driver of Canada's Future ProsperityAdvisory Panel on Canada's International Education Strategy (Final Report).

Dornyei, Z. \& Ushioda, E. (Eds.). (2009) Motivation, Language Identity, and the L2 Self. Bristol: Multilingual Matters.

Duff, P.A. (2008) Language, socialization, higher education, and work. In P.A. Duff \& N. H. Hornberger (eds.), Encyclopedia of Language and Education: Vol. 8. Language Socialization (pp. 257-270). New York: Springer.

Duff, P. A. (2010). Language socialization into academic discourse communities. Annual Review of Applied Linguistics, 30, 169-192.

Feast, V. (2002). The impact of IELTS scores on performance at university. International Education Journal, 3, 70-85.

Furnham, A. \& Erdmann, S. (1995). Psychological and socio-cultural variables as predictors of adjustment in cross-cultural transitions. Psychologia, 38, 238-251. 
Gardner, R.C. \& Lambert, W.E. (1972). Attitudes and motivation in second language learning. Rowley, MA: Newbury House.

Gareis, E. Merkin, R. \& Goldman, J. (2011). Intercultural friendship: Linking communication variables and friendship success. Journal of Intercultural Communication Research, 40, 153-171.

Gargano, T.(2012). Grounded identities, transient lives: The emergence of international student voices in an era of cosmopolitan learning. Journal of International Students, 2, 144-157.

Gomes, C. \& Alzougool, B. (2013). Transnational citizen and identities: Intenrational students' self-Australia In C. Gomes \& S. Chang (Eds.) Proceeding of the $24^{\text {th }}$ ISANA Internatioanl Education Association Conference Proceedings, Hobart, 3-6 December, 2013, pp. 1-15.

Grimshaw, T. (2011). The needs of international students rethoughtimplications for the policy and practice of higher education. Teachers and Teaching: Theory and Practice, 17, 703-712.

Grayson, J. P. (2008). The experiences and outcomes of domestic and international students at four Canadian universities. Higher Education Research and Development, 27, 215-230.

Gu, Q., Schweisfurth, M. \& Day, C. (2009). Learning and growing in a 'foreign' context: intercultural experiences of international students. Compare: A Journal of Comparative and International Education, 40, 723.

Halic, O., Greenberg, K. \& Paulus, T. (2009). Language and academic identity: A study of the experiences of non-native English speaking international students. International Education, 38, 73-95.

Hayashi, H. (2013). Becoming a student: Multilingual university students' identity construction in Simon Fraser University. Unpublished dissertation.

Hayes, R. \& Lin, H.R. (1994). Coming to America: Developing social support systems for international students. Journal of Multicultural Counselling and Development, 22, 7-16.

Holliday, A. R. (2005). The Struggle to Teach English as an International Language. Oxford: Oxford University Press.

Horwitz, E. K., Horwitz, M.B., \& Cope, J. (1986). Foreign language classroom anxiety. The Modern Language Journal, 10, 125-132.

Hullet, C. \& Witte, K. (2001). Predicting intercultural adaption and isolation: Using the extended parallel process model to test anxiety/uncertainty management theory. International Journal of Intercultural Relations, 25, 125-139.

Hung, H.-L. \& Hyun, E. (2010). East Asian international graduate students' epistemological experiences in an American university. International Journal of Intercultural Relations, 34, 340-353. 
Ippolito, K. (2007). Promoting intercultural learning in a multicultural university: Ideals and realities. Teaching in Higher Education, 12, 749763.

Jackson, A. Y. (2013). Data-as-Machine: A Deleuzian becoming. In R. Coleman \& J. Ringrose (Eds.), Deleuze and Research Methodologies. (pp. 111-124). Edinburgh: Edinburg University Press.

Jackson, A. Y. \& Mazzei, L.A. (2012). Thinking with Theory in Qualitative Research: Viewing Data Across Multiple Perspectives. New York: Routledge.

Jackson, J. (2011). Cultivating cosmopolitan, intercultural citizenship through critical reflection and international, experiential learning. Language and Intercultural Communication, 11, 80-96.

Jackson , J. (2008). Language, Identity, and Study Abroad: Sociocultural Perspectives. London: Equinox.

Kinginger, C. (2013). Identity and language learning in study abroad. Foreign Language Annals, 46, 339-358.

Knight, J. (2011). Five myths about internationalization in post-secondary education. International Higher Education, 62, 14-15.

Kramsch, C. (2001). Beyond the second vs. foreign language dichotomy: The subjective dimensions of language learning. Paper presented at the Conference on Unity and Diversity in Language Use, University of Reading.

Kramsch, C. (2009). The multilingual subject. Oxford, UK: Oxford University Press.

Kubota, R. \& Lin, A. (2006) (Eds.), Race and TESOL. Special Topic Issue of TESOL Quarterly.

Lave, J. \& Wenger, E. (1991). Situated learning: Legitimate peripheral participation. Cambridge, Uk: Cambridge University Press.

Lee, G. (2009). Speaking-up: Six Korean students’ oral participation in class discussions in US graduate seminars. English for Specific Purposes, 28, 142-156.

Li, A. \& Gasser, M. (2005). Predicting Asian international students' sociocultural adjustment: A test of two mediation models. International Journal of Intercultural Relations, 29, 591-576.

Li, R., \& Kaye, M. (1998). Understanding overseas students' concerns and problems. Journal of Higher Education Policy and Management, 20, 4150.

Lin, L. F. (2009). Second language learners' identity toward their home culture: Adding pragmatic knowledge to language learning curriculum. Asian Social Science, 5, 43-52. 
Magyar, A. \& Robinson-Pant, A. (2011). Special issue on university internationalization: Toward transformative change in higher education. Teachers and Teaching: Theory and Practice, 17, 663-676.

Mallinckrodt, B. \& Leong, F.T.L. (1992). International graduate students, stress, and social support. Journal of College Student Development, 33, 71-78.

Marshall, S. (2010). Re-becoming ESL: Multilingual university students and a deficit identity. Language and Education, 24, 41-56.

Martin, A. D. \& Kamberelis, G. (2013). Mapping not tracing: qualitative educational research with political teeth. International Journal of Qualitative Studies in Education, 26, 668-679.

Masny, D. (2013). Rhizoanalytical pathways in qualitative research. Qualitative Inquiry, 19, 339-348.

Matsumoto, D., Le Roux, J., Berhand, R. \& Gray, H. (2004). Unraveling the psychological correlates of intercultural adjustment potential. International Journal of Intercultural Relations, 28, 281-309.

Mazzei, L. A. (2013). A voice without organs: Interviewing in posthumanist research. International Journal of Qualitative Studies in Education, 26, 732-740.

McElhinny, B. (2010). The audacity of affect: Gender, race, and history in linguistic accounts of legitimacy and belonging. Annual Review of Anthropology, 39, 309-328.

Menard-Warwick, J. (2005). Both a fiction and an existential fact: Theorizing identity in second language acquisition and literacy studies. Linguistics and Education, 16, 253-274.

Morita, N. (2009). Language, culture, gender, and academic socialization. Language and Education, 23, 443-460,

Mittal, M., \& Wieling, E. (2006). Training experiences of international students in higher education: What college counselors and personnel need to know. Journal of Instructional Psychology, 33, 217-222.

Norton, B. (1995). Social identity, investment, and language learning. TESOL Quarterly, 29, 9-31.

Norton, B. (1997). Language, identity, and the ownership of English. TESOL Quarterly, 31, 409-429.

Norton, B. (2000). Identity and language learning: Gender, ethnicity, and educational change. Harlow, English: Longman/Pearson.

Olivas, M. \& Lee, C. (2006). Understanding stressors of international students in marriage. Journal of Marital and Family Therapy, 32, 369383.

Pavlenko, A. (2013). The affective turn in SLA: From 'Affective factors' to 'Language desire' and 'Commodification of affect'. In D. Garbys-Barker 
\& J. Bielska (Eds.), The Affective Dimension in Second Language Acquisition, (pp. 3-28). London: Multilingual Matters.

Pavlenko, A. \& Lantolf, J.P. (2000). Second language learning as participation and the (re)construction of selves. In J.P. Lantolf (Ed.), Sociocultural Theory and Second Language Learning (pp.669-680). New York: Springer.

Perrucci, R. \& Hu, H. (1995). Satisfaction with social and educational experiences among international graduate students. Researcher in Higher Education, 36, 491-508.

Phakiti, A. Hirsch, D. \& Woodrow, L. (2013). It's not only English: Effects of other individual factors on English language learning of ESL international students in Australia. Journal of Research in International Education, 12, 239-258.

Phelps, J.M. (2013). Otherwise, elsewhere: International doctoral students in globalized transnational space. Doctoral dissertation from https://circle.ubc.ca/bitstream/handle/2429/44158/ubc_2013_spring_phel ps_jennifer.pdf?sequence $=1$

Phillips, D. \& Schweisfurth, M. (2014). Comparative and international education: An introduction to theory, method, and practice. $\left(2^{\text {nd }}\right.$ ed.). New York: Bloomsbury Press.

Pickering, A. (1993). The mangle of practice: Agency and emergence in the sociology of science. American Journal of Sociology, 99, 559-589.

Poyrazli, S. \& Grahame, K. M. (2007). Barriers to adjustment: Needs of international students within a semi-urban campus community, Journal of International Psychology, 34, 28-36.

Poyrazli, S., Kavanaugh, P.R., Baker, A., \& Al-Timini, N. (2004). Social support and demographic correlates of acculturative stress in international students. Journal of College Counseling, 7, 73-83.

Poyrazli, S., \& Lopez, M.D. (2007). An exploratory study of perceived discrimination and homesickness: A comparison of international students and American students. The Journal of Psychology, 141, 263-279.

Redmond, M.V. \& Byuni, J. M. (1993). The relationship of intercultural communication competence with stress and the handling of stress as reported by international students. International Journal of Intercultural Relations, 17, 235-254.

Ramsay, S., B., Barker, M. \& Jones, E. (1999). Academic adjustment and learning processes: A comparison of international and local students in first-year university. Higher Education Research \& Development, 18,129144.

Roberston, M., Line, M., Jones, S. \& Thomas, S. (2010). International students, learning environments and perceptions: A case study using the delphi technique. Higher Education and Development,19, 89-102. 
Ryan, J. (2011). Teaching and learning for international students: Towards a transcultural approach. Teachers and Teaching: Theory and Practice, 17, 631-648.

Sam, D. Vedder, P. \& Ward, C. (2006). Psychological and sociocultural adjustment. In J.W. Berry \& J, Phinney (Eds.), Immigrant Youth in Cultural Transition: Acculturation, Identity, and Adjustment Across National Contexts. Hillsdale, NJ: Lawrence Erlbaum.

Sandhu, D.S. \& Asrabadi, B.R. (1994). Development of an acculturative stress scale for international students: Primary findings. Psychological Reports, 75, 435-448.

Sawir, E., Marginson, S., Forbes-Mewett, H. Nyland, C. \& Ramia, G. (2012). International student security and English language proficiency. Journal of Studies in International Education, 16, 434-454.

Schecter, S. R. \& Bayley, R. (2004). Language socialization in theory and practice. International Journal of Qualitative Studies in Education, 17, 605-625.

Searle, W. \& Ward, C. (1990). The prediction of psychological and sociocultural adjustment during cross-cultural transitions. International Journal of Intercultural Relations, 14, 449-464.

Schweisfurth, M. \& Gu, Q. (2009). Exploring the experience of international students in UK higher education: possibilities and limits of interculturality in university life. Intercultural Education, 20, 463-473.

Seloni, L. (2011). Academic literacy socialization of first year doctoral students in US: A micro-ethnographic perspective. English for Specific Purposes, 31, 47-59.

Street, B.V. (1996). Academic literacies. In D. Baker, J. Clay, \& C. Fox (Eds.), Challenging Ways of Knowing: In English, Mathematics and Science (pp. 101-134). London: Falmer Press.

Trice, A. (2003). Faculty perceptions of graduate international students: The benefits and challenges. Journal of Studies in International Education, 7, 379-403.

Trilokekar, R. D. \& Kizilbash, Z. (2013). IMAGINE: Canada as a leader in international education. How can Canada benefit from the Australian experience? Canadian Journal of Higher Education, 43, 1-26.

Uysal, H.H. (2010). A critical review of the IELTS writing test. ELT Journal, 64, 314-320.

Ward, C. Bochner, S., \& Furnham, A. (2008). The Psychology of Culture Shock $\left(2^{\text {nd }}\right.$. ed. $)$.London: Routledge.

Ward, C. \& Kennedy, A. (1992). Locus of control, mood disturbance and social difficulty during cross-cultural transitions. International Journal of Intercultural Relations, 16, 175-194. 
Ward, C. \& Masgoret, A.M. (2004). The experiences of international students in New Zealand. Report on the results of the national survey. Available at http://www.edcuationcounts.govt.nz/publications/international/147 Wilton, L. \& Constance, M.G. (2003). Length of residence, cultural adjustment difficulties, and psychological distress symptoms in Asians and Latin American international college students. Journal of College Counseling, 6, 177-187.

Wright, C. \& Schartner, A. (2013). 'I can’t...I won't?' International students at the threshold of social interaction. Journal of Research in International Education, 12, 113-128.

Yang, R., Noels, K. \& Saumure, K. (2006). Multiple routes to cross-cultural adaptation for international students: Mapping the paths between selfconstructs, English language confidence, and adjustment. International Journal of Intercultural Relations, 30, 487-506.

Yeh, C. J. \& Inose, M. (2003). International students' reported English fluency, social support satisfaction, and social connectedness as predictors of acculturative stress. Counselling Psychology Quarterly, 16, 15-28.

Zamel, V. (1997). Toward a model of transculturation. TESOL Quarterly, 31, 341-352.

Zhang, Y. \& Mi, Y. (2013). Another look at the language difficulties of international students. Journal of Studies in International Education, 14, 371-388.

Zhou, Y., Jindal-Snape, D., Topping, K., \& Todman, J. (2008). Theoretical models of culture shock and adaptation in international students in higher education. Studies in Higher Education, 33, 63-75.

GENE VASILOPOULOS is a doctoral candidate in education with a focus on second language development. Her research interests include language learning and identity, international students' adjustment to higher education, and language learning/use in dynamic social contexts. Email: evasi026@uottawa.ca 